\title{
Het vaststellen van de mate van religieuze tolerantie bij leraren in opleiding
}

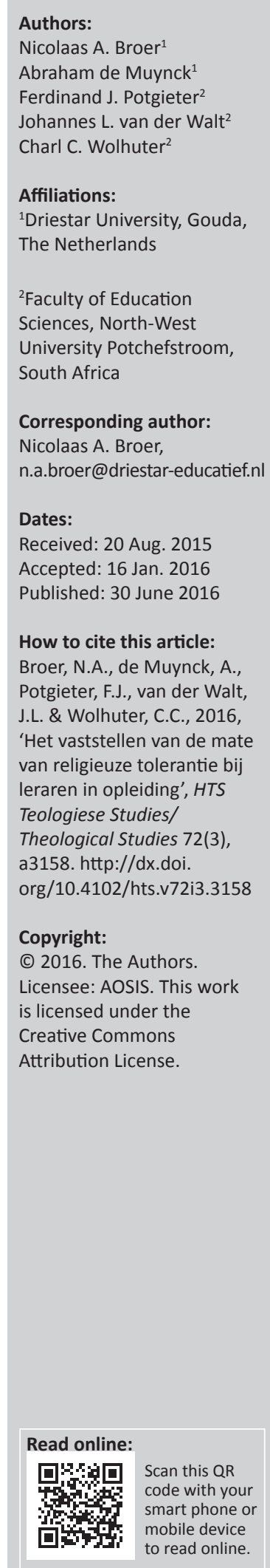

In recent years, schools and education authorities worldwide have been paying increased attention to issues surrounding diversity and religious tolerance. Tolerance constitutes one of the most important preconditions for social justice, fairness and peaceful coexistence. Hence, the authors of this article decided to develop an instrument measuring the degree and nature of religious tolerance among student teachers. It is not this article's purpose to enter into a discussion about how to actually resolve religious, cultural and political conflict, but merely to embark on the process of developing an instrument to measure the degree of religious tolerance among teachers and student teachers.

Religious intolerance is increasingly viewed as problematic, and it appears that education has been assigned the role of inculcating religious tolerance in young people. Teachers are expected to be able to inculcate in their students the respect, empathy, critical thinking and acceptance of differences among people associated with the notion of tolerance. To be able to do this, teachers have to possess the traits of a tolerant person.

Whether teachers are indeed tolerant in practice depends on the extent to which they have mastered the capacity to be tolerant. This article reports on a study that culminated in the construction of a questionnaire for measuring the degree to which students on the threshold of entering the teaching profession displayed a tolerant attitude.

The construction of the questionnaire was based on a theoretical study of tolerance and intolerance. The questionnaire was then applied in three different countries (South Africa, the Netherlands and India). Factor analyses were performed on the data to establish the validity of the instrument.

The first round of application revealed a number of shortcomings in the questionnaire. The study therefore recommends a revision of the questionnaire. Among other things, the factoral structure and the reliability of some of the sub-scales require further attention. The study ascribes the lower than expected explanation of variance in the data set to the cultural differences existing among the different groups of respondents in the three countries.

The article closes by drawing a conclusion regarding the degree of religious tolerance among the respondents who participated in this first round of application of the questionnaire.

\section{Inleiding}

\section{Aandacht voor religieuze tolerantie}

In de afgelopen twee decennia hebben veel wetenschappelijke publicaties over religieuze tolerantie en intolerantie het licht gezien (cf. Bower 2005:43; Gray 2009:21-25; Grayling 2002:7-9; Grayling 2010:220; Morton 1998:167-198; Potgieter \& Van der Walt 2014:1, 2; Schreiner 2005:6, 15; Van der Walt 2007:160-213; Wright 2009:413-428). De urgentie van het onderwerp is toegenomen doordat samenlevingen in cultureel en religieus opzicht een steeds ongelijksoortiger en meer uiteenlopend karakter aannemen. Ook in academische debatten speelt het onderwerp een belangrijke rol, in het bijzonder als het gaat over het verband tussen onderwijs en opvoeding en religieuze tolerantie (cf. Coleman \& White 2011; Van der Walt 2007:195-197; Vermeer \& Van der Ven 2004:36). In diverse landen stelt de radicalisering van, bijvoorbeeld, moslimjongeren politici en onderwijsmensen voor vragen die voorheen niet werden gesteld.

In het debat over maatschappelijke problemen speelt het onderwijs vaak een belangrijke rol. Eén van de belangrijkste redenen daarvoor is het feit dat intolerant gedrag in onderwijsomgevingen (zowel in klaslokalen als daarbuiten) zich manifesteert in de vorm van beledigingen, pesten, groepsvorming en het neerhalen van de mening van anderen in groepsdiscussies. Daarmee is de school een afspiegeling van wat er in de samenleving gebeurt. Evenals in de gehele samenleving 
wordt ook op scholen intolerantie gevoed door angst. Angst wordt weer bevorderd door onbekendheid met de ander en verkeerde informatie over de ander (Nussbaum 2012:29 e.v.). Angst voor het onbekende kan tot xenofobisch gedrag aanleiding geven, in die zin dat de 'ander' tot 'vreemdeling' gedegradeerd wordt (Bol 2015:2).

Van scholen wordt verwacht dat zij een rol van betekenis spelen bij het oplossen van maatschappelijke problemen. Omdat in het onderwijs naast het aanleren van de cultureelinstrumentele vaardigheden de vorming van de persoon van de leerling aan de orde is, mag inderdaad worden verwacht dat scholen inspelen op ontwikkelingen die zich in de maatschappij voordoen. Dat geldt ook voor de lerarenopleidingen. In de afgelopen jaren besteedden scholen en andere onderwijsinstanties dan ook in toenemende mate aandacht aan onderwerpen als diversiteit en religieuze tolerantie (cf. Collins 2009; Goodin 2006; Ignatieff 2004; Jarvis 2009; Pape 2005; Qualifications and Curriculum Authority 2004, 2010; Roux 2000, 2006; Sardoc 2010).

In dit artikel worden religieuze tolerantie en de noodzaak om daarmee bezig te zijn benaderd vanuit de lerarenopleiding. De probleemstelling van het onderzoek waarover hier gerapporteerd wordt, is: Hoe kan de mate van religieuze tolerantie van aanstaande leraren worden vastgesteld?

Om deze vraag te kunnen beantwoorden, moeten we weten hoe religieuze tolerantie kan worden beschreven en waarom het belangrijk is om daar in het onderwijs aandacht aan te besteden. In het conceptueel-theoretische raamwerk wat hierna volgt (literatuuroverzicht), worden deze vragen beantwoord. Vervolgens wordt het empirische onderzoek dat is uitgevoerd beschreven.

\section{Conceptueel en theoretisch raamwerk (inclusief literatuuroverzicht)}

\section{De begrippen 'tolerantie' en 'religieuze tolerantie'}

In de literatuur worden talloze pogingen gedaan om 'tolerantie' te definiëren (e.g. Tobing 2013; Visanmiu 2012). De meeste conceptuele definities richten zich op menselijke eigenschappen, zoals attitude, bekwaamheid, actie, bepaalde vormen van gedrag of respons. De meeste definities dekken bovendien een breed spectrum aan waarden (Van der Walt, Potgieter \& Wolhuter 2010).

Volgens Vermeer en Van der Ven (2004) en Cush en Francis (2006) kan (religieuze) tolerantie worden gesitueerd in een spectrum. Aan het ene eind van het spectrum wordt tolerantie begrepen als een houding van verdraagzaamheid en inclusiviteit ten opzichte van medemensen die verschillen in opvattingen, gebruiken, ras, religie, nationaliteit enzovoorts. Aan het andere einde van het spectrum vinden we extreem intolerant gedrag dat veroorzaakt wordt door radicale standpunten die het gevolg zijn van religieus extremisme en exlusivisme, fundamentalisme en zelfs fanatisme. Rond het midden van dit spectrum wordt tolerantie opgevat als een houding die vrij is van fanatisme en tevens respect voor (de waardigheid van) anderen weerspiegelt, voor hun gewetensvrijheid en voor godsdienstige verschillen. In de kern kan tolerantie worden gezien als het vermogen om de ander en het andere met geduld te behandelen, hoe verschillend die ander ook is. Wanneer deze omschrijving op zichzelf genomen wordt, kan ze minimalistisch gelezen worden als 'dulden' zonder dat er sprake is van 'erkenning' (Furedi 2012). Om aan dit bezwaar tegemoet te komen is er meer nodig. Daarom onderstrepen we in het vervolg van deze afdeling vier aspecten die vanuit recente theorievorming over tolerantie van groot belang kunnen worden geacht.

\section{Tolerantie heeft alleen betekenis als er verschillen aanwezig zijn}

Tolerantie kan worden beschouwd als een positieve houding tegenover het feit dat een mens het recht heeft om zelfstandig te kiezen wat hij wil denken, wat hij wil doen en welk gedrag hij wil vertonen (Furedi 2012:30-31, 37). Daarbij wordt ervan uitgegaan dat ieder het recht heeft om de zin van het leven te zoeken en te vinden op een manier die in overeenstemming is met het eigen geweten (Nussbaum 2012:241). Saulius (2013:49) stelt dat tolerantie een belangrijke democratische waarde is. In dit artikel wordt tolerantie echter veel ruimer gezien. Het gaat vooral om het vreedzaam samenleven: mensen behoren elkaar en de onderlinge verschillen zo te verdragen (tolereren) dat ze in vrede menswaardig samen kunnen leven. ${ }^{1}$ Tolerantie veronderstelt dat elk mens de vrijheid heeft om zichzelf tot uitdrukking te brengen (Joe 2011) in zijn of haar bijzondere omstandigheden (Van der Walt 2014). Tolerantie kan er slechts zijn als ieder mens recht heeft op vrijheid van geweten en op zelfstandigheid (Furedi 2012:31). De verschillen tussen mensen die in dit opzicht aan het licht komen, moeten geëerbiedigd en gerespecteerd worden (Potgieter \& Van der Walt 2014:3).

In een poging om duidelijk te maken dat tolerantie een op de ander gerichte houding is die niet voorkomt uit een zelfgecentreerd, egoïstisch eigenbelang, onderstreept Potgieter (2015:55) in navolging van Derrida en Keet dat tolerantie stelselmatig behoort te verdiepen tot het beoefenen van 'gastvrijheid': de zuivere en onvoorwaardelijke gastvrije ontvangst van en het bij voorbaat beschikbaar zijn voor iemand die zelfs onverwacht en ongenood binnenkomt. Nussbaum (2012:97) gebruikt hiervoor de metafoor van de 'stijlvolle gastvrouw'. De goede gastvrouw laat ten opzichte van ieder mens met wie zij in aanraking komt blijken dat zij met hem meevoelt op een manier die haar eigen belang overstijgt, dat zij hem als haar gelijke erkent en als zodanig met hem omgaat en dat haar eigen religieuze opvatting niet de enige is die telt of aanvaardbaar is. Als gastvrouw beschikt zij over een rijke (morele en nieuwsgierige) verbeelding die gericht is op anderen en hun omstandigheden (Nussbaum 2012:241). Tolerantie is dus een positieve waardering van de verschillen tussen mensen en zelfs van botsende visies (Furedi 2012:37).

1. In het vervolg van dit artikel komt het vraagstuk van 'democratie' nog terug In alle gevallen moet dit with altijd he vreedzaam samenleven van mensen ten doel, als gevolg van het begrijpen, verdragen en dulden van de verschillen die er zijn tussen individuen engroepen. Dit geldt ook binnen het staatsbestel van een land. Het geldt dus ook voor een democratie (regering door het volk), waarnaar in dit artikel verschillende keren verwezen wordt. 
Tolerantie komt slechts aan het licht wanneer iemand beseft dat hij of zij geen andere mogelijkheid heeft dan de opvattingen en het gedrag van andere mensen en groepen te verdragen ter wille van een goed, positief en vreedzaam samenleven. Het verdragen van verschillen is, zoals Saulius (2013) aanduidt, een erkenning van het feit dat alle leden van een samenleving een beroep kunnen doen op dezelfde mensenrechten en dat het bestaan van verschillen een kerngegeven is in hedendaagse samenlevingen. De erkenning van verschillen is meteen een erkenning van de medemensen als volledige, gelijke en gelijkwaardige leden van de samenleving (Galeotti 2014:9).

\section{Tolerantie is alleen daar waar ook respect is voor de ander, voor diens grondrechten en voor diens menswaardigheid}

Alle mensen hebben recht op een gelijke mate van eerbied of respect van alle andere mensen (Galeotti 2014:8). Dat recht hebben zij niet slechts omdat zij lid zijn van een moderne samenleving die op liberale leest geschoeid is, maar vooral omdat zij als mens in beginsel als gelijkwaardig aan anderen geschapen zijn. Als gelijkwaardigen geschapen, hebben alle mensen recht op gelijke behandeling, op sociale gerechtigheid en op een billijke behandeling. Zonder de erkenning van dit fundamentele recht van de mens is een relatief vreedzaam samenleven niet mogelijk, aldus Furedi (2012:30-31, 37). Een vreedzame samenleving kan niet gefundeerd zijn in de voorkeuren van individuen, van de meerderheid in de samenleving, of van de overheid. Vreedzaam samenleven in een gemeenschap is slechts mogelijk als dat ingebed is in een sfeer die daartoe de omstandigheden schept. Als iemand die omstandigheden bedreigt, of zelfs onmogelijk maakt, moet er onvermijdelijk tegen zo iemand worden opgetreden.

Tegenover de positieve waardering van verschillen en zelfs botsende opvattingen moet met Boersma (2012) worden gesteld dat individuen en groepen niet over een absolute vrijheid beschikken. Mensen en groepen van mensen zijn niet totaal vrij om te doen wat ze willen. Iedereen is gebonden aan bepaalde gedragsnormen. Op grond van dit uitgangspunt heeft elk mens ook recht om kritisch te zijn over het denken van anderen en om te discrimineren, dat wil zeggen om onderscheid te maken tussen wat goed en verkeerd is op grond van algemeen aanvaarde (sociale) normen (Furedi 2012:31-37; Joe 2012:32). Maar iemand die kritisch tegenover het denken of het gedrag van een ander staat, hoeft dat niet noodzakerlijkerwijs uit te spreken of de ander te verwerpen (zie hieronder 'Tolerantie veronderstelt kritisch oordelen').

\section{Tolerantie is alleen daar waar empathie is}

In bijbelse termen komt de gedachte van de titel boven deze paragraaf neer op het gebod 'de ander lief te hebben als zichzelf'. Tolerantie heeft in dit opzicht een duidelijke ethische kant: het gaat erom dat een mens de belangen van de ander op dezelfde wijze behartigt als waarop hij die van zichzelf zou behartigen. Bij onaanvaardbaar denken of gedrag van een ander moet men zich afvragen of hij de belangen van die persoon net zo zou behartigen als zijn eigen belangen, of dat hij dat anders zou doen. Dit kan men alleen vaststellen met 'morele verbeelding': het jezelf verplaatsen in de ander. Door empathische verbeelding (Nussbaum 2012:21, 28) kan iemand de drijfveren achter het denken en optreden van een ander begrijpen en op gepaste (tolerante) wijze reageren (Bucher \& Manning 2010:160-163; Skiba \& Peterson 1999:9-10). Door deze verbeelding kan men zich ook voorstellen welke last iemand met een andere godsdienst te dragen heeft en hoe hij naar de werkelijkheid kijkt. Verbeelding weerhoudt een mens ervan om een ander en zijn godsdienst slechts als verkeerd en strijdig met of beledigend voor de opvatting van de meerderheid te beschouwen (Nussbaum 2012:96).

Het zich verplaatsen in de denkwereld van de ander is een veeleisende opdracht. Biesta (2013:116) meent dat empathie niet te gemakkelijk opgenomen moet worden, omdat het woord suggereert dat men onbekommerd de positie van de ander in kan nemen. Dat gaat niet zonder ongemakkelijke gevoelens. Die moet men niet proberen te vermijden. In plaats van empathie spreekt hij dan ook liever van 'visiting' waaronder hij verstaat dat je met je eigen ogen ziet vanuit een positie die niet van jezelf is.

\section{Tolerantie veronderstelt kritisch oordelen}

Tolerantie vergt zelfbeheersing ('restraint') en erkenning van het recht van de ander om de eigen weg naar de waarheid te zoeken en te volgen (Furedi 2012:32). Beoefening van tolerantie in een land, natie of ander groepering bestaat echter niet eenvoudig uit het toestaan van alternatieve inzichten naast elkaar. Tolerantie vereist ook dat men in staat en bereid is om zich over het denken en optreden van de ander een oordeel te vormen. Het vergt 'engagement' met de morele of ethische keuze waarvoor men zelf komt te staan én engagement met de denkkracht van de ander (cf. Furedi 2012:32; Nussbaum 2012:174, 210). Voor daadwerkelijke tolerantie dient er dus ook een grote motivatie te zijn om zich intensief in iemand anders standpunten te verdiepen en deze aan een kritisch oordeel te onderwerpen. Daarover moet ook gecommuniceerd worden. Weigering om met de ander een gesprek te voeren over motieven en uitgangspunten moet dan ook beschouwd worden als intolerantie (Nussbaum 2001:417; Saulius 2013:54).

\section{Religieuze tolerantie, onderwijs en de lerarenopleiding}

\section{Het verband tussen religieuze identiteitsontwikkeling en tolerantie}

De ontwikkeling van bovengenoemde voorwaarden voor tolerantie zal in de identiteitsontwikkeling van jongeren moeten plaatsvinden. Dit is de periode waarin jongeren bezig zijn om overtuigingen die ze eerder hebben gezien en gehoord te integreren in een persoonlijke identiteit. De integratie bevordert dat men wil gaan handelen in overeenstemming met zijn of haar eigen identiteit. De vier voorwaarden die hierboven genoemd zijn (het aanvaarden van verschillen, respect voor ieders menswaardigheid, het ontwikkelen van een empathische houding en het in staat zijn tot kritisch toetsen van andermans overtuiging) kan men 
zien als behorend tot de morele aspecten van deze identiteit (Hart, Atkins \& Ford 1998:515). Bij jongeren die zich bewust aan een religie committeren is na te gaan hoe hun religieuze ontwikkeling hun morele houding beïnvloedt. Visser-Vogel (2015:113-132) onderzocht hoe strenggelovige Nederlandse moslimjongeren zich verhouden tot de Nederlandse samenleving. Deze jongeren blijken zich kritisch op te stellen ten opzichte van de samenleving en blijken zich vooral verbonden te voelen met hun eigen groep. Op het eerste gezicht zou men hierin een basis voor intolerantie kunnen zien. Het ligt echter genuanceerder. Jongeren neigen ertoe het geloof als iets persoonlijks te zien en participatie aan de samenleving als iets dat op zichzelf geen problemen oplevert, tenzij het zaken betreft die de Islam niet toestaat. Men heeft echter het vermogen om zelf bruggen te slaan tussen het gelovig zijn en het staan in de samenleving. Het onderwijs dat deze jongeren ontvangen, lijkt er toe bij te dragen dat ze beter hun verbondenheid met het eigen geloof kunnen verwoorden maar tevens ook in staat zijn als burgers te participeren in de samenleving.

\section{Tolerantie en onderwijs}

De noodzakelijke bijdrage van onderwijs aan burgerschapsvorming ${ }^{2}$ wordt wereldwijd onderkend. Uit onderzoek van Schulz et al. (2010) in 38 landen verspreid over Europa, Latijns-Amerika en Azië, waaronder Nederland, blijkt dat op meer dan 75 procent van de scholen één of andere vorm van burgerschapsonderwijs gehanteerd wordt. Als voorbeeld van deze aandacht wijzen we op het Schotse 'curriculum for excellence' (The curriculum review group 2004). Het kerndoel 'verantwoord burgerschap' wordt onder andere uitgewerkt als 'respect hebben voor anderen'. Om respect te bereiken moet het curriculum de rechten en verantwoordelijkheden van individuele personen en naties benadrukken. Het moet jongeren helpen om andere culturen en opvattingen te begrijpen en hen helpen om betrokkenheid, tolerantie, zorg en respect voor zichzelf en anderen te ontwikkelen. Het Schotse curriculum richt zich dus nadrukkelijk op het omgaan met verschillen en op tolerantie.

Onderwijs kan derhalve bijdragen aan een set van kwaliteiten die onderdeel zijn van goed burgerschap. Biesta (2013:103) legt er de vinger bij dat democratie gemakkelijk tot een externe waarde van onderwijs gerekend wordt. ${ }^{3}$ Het democratische burgerschap wordt verschoven tot iets ná het onderwijs. Ten onrechte wordt dan verondersteld dat democratie een vanzelfsprekend resultaat is van een goed opgeleide bevolking. Biesta bepleit een visie waarin democratisering niet een externe maar een interne waarde van onderwijs is. De vrijheid om een eigen overtuiging op te bouwen en andere overtuigingen te kritiseren moet, met andere woorden, binnen het onderwijs zelf beoefend worden. Onderwijs 'produceert' geen democratie, maar zorgt voor de

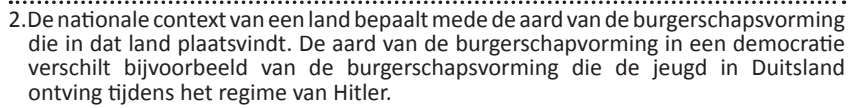
die in dat land plaatsvindt. De aard van de burgerschapvorming in een democratie verschilt bijvoorbeeld van de burgerschapsvorming die de jeugd in Duitsland ontving tijdens het regime van Hitler.

3.De uitspraken van Biesta zijn acceptabel, mits ze gezien worden in de context van wat in de voetnoten 1 en 2 is gesteld. condities waarin democratische vrijheden worden gevormd (Biesta 2013:101-118). Deze visie heeft ook gevolgen voor de lerarenopleidingen. In de opleiding moet men aanstaande leraren zo vormen dat ze in staat zijn om het vormen van overtuigingen en het kritiseren van overtuigingen en ook tolerantie met betrekking tot de overtuigingen van anderen mogelijk maken.

\section{De taak van de lerarenopleiding}

Het einde van de adolescentie, en dus van de morele identiteitsvorming, wordt over het algemeen geplaatst tussen het 20e en 30e levensjaar (Boer 2014; Slot \& Van Aken 2013), afhankelijk van de cultuur waarin men leeft. De afsluiting van de lerarenopleiding valt in deze periode. Wat er in de jaren daarvoor gebeurt, is dus van groot belang. Wat studenten aan overtuigingen gezien en gehoord hebben, komt dan tot een geïntegreerd verband. Vanuit die eigen identiteit zullen zij om moeten gaan met andere identiteiten en daarin voorbeeldgedrag voor leerlingen moeten tonen. In het genoemde onderzoek onder toegewijde Moslimjongeren vond Visser-Vogel (2015) dat leraren een grote rol speelden in de identiteitsvorming van de leerlingen, zelfs meer dan hun ouders. Dit onderstreept het belang van de lerarenopleiding voor het burgerschap van volgende generaties leerlingen.

In zijn boek, Knowledge in the blood: Confronting race and the Apartheid past, bespreekt Jansen (2010) de spanning en het conflict tussen de opvattingen, overtuigingen, waarden en attitudes die jongeren voornamelijk overnemen van hun ouders, familie, vrienden, de scholen die zij bezochten en hun kerken enerzijds, en de identiteitsgerelateerde kennis die ze nodig hebben om effectief te functioneren als burger in een moderne samenleving anderzijds. Deze twee sets van kennis noemt Jansen 'indirecte kennis' /'erfelijke kennis' en 'directe kennis'. De verbinding tussen enkele van de meest recente wetenschappelijke gegevens op het gebied van neuropsychologie, het begrip identiteit-formatie en 'indirecte/ erfelijke kennis', evenals religieuze (in)tolerantie is uitgewerkt in Jesse Berings boek: The God instinct: The psychology of souls, destiny and the meaning of life. Bering (2010) betoogt onder andere dat (religieus) tolerant of intolerant gedrag (en dus iemands 'indirecte/erfelijke kennis') is gekoppeld aan zijn/haar overtuiging dat de subjectieve psychologische effecten die het gevolg zijn van zijn/haar eigen cognitieve vertekeningen (inclusief zijn/haar religie en religiositeit) in feite een objectieve realiteit weerspiegelen (2010:147-190).

We wijzen erop dat deze onderstreping ook door anderen gegeven is in verband met wereldwijd toenemende sociale mobiliteit, internationalisering en pluralisering en de daarmee gepaard gaande waardeverwarring en waardemobiliteit (Richardson, Imig \& Flora 2014:354; Van Schoonacker-De Groot 2011; Wolhuter 2016:24). De claim die dit legt op de lerarenopleiding maakt de ontwikkeling van een vragenlijst om de mate van (religieuze) tolerantie bij leraren in opleiding te meten meer dan noodzakelijk. 


\section{Van theorie naar vragenlijst}

In deze paragraaf slaan wij een brug van de theorie over religieuze tolerantie (zoals hierboven gegeven en in detail beschreven in Potgieter, Van der Walt \& Wolhuter 2014; Van der Walt 2014) naar een aantal implicaties voor de praktijk van het samenleven in een pluralistische samenleving. In de beschrijving verduidelijken wij tevens de rationale achter het opnemen van bepaalde items in de vragenlijst waarover dit artikel handelt.

De levens- en wereldbeschouwing van een leraar speelt een doorslaggevende rol in zijn of haar tolerantie (Olthuis 2012:4, 7). Daarom wordt aan de respondenten gevraagd naar hun religieuze overtuiging (Zijn ze religieus? Zo ja, behoren ze tot een georganiseerde religieuze groepering? En zo ja, tot welke? Of zien zij zichzelf als 'spiritueel'?) Aan respondenten wordt ook gevraagd hoe bewust zij zich zijn van hun levens- en wereldbeschouwing en in hoeverre zij daarmee in overeenstemming leven.

Ten tweede veronderstellen we met Olthuis (2012) dat betrokkenheid op de ander en op de omgeving cruciaal zijn voor de tolerantie van een persoon. Daarom bevat de vragenlijst items die gaan over het vertrouwen in anderen en de openheid naar de omgeving. Ook wordt nagegaan in hoeverre respondenten bezig zijn hun eigen behoeften te bevredigen of open staan voor de behoeften van anderen, of zij al dan niet iets van anderen verwachten en of zij anderen en de omgeving ervaren als een bedreiging.

Vervolgens wordt nagegaan in hoeverre respondenten gericht zijn op zichzelf of op het algemeen belang. Verondersteld wordt namelijk dat de plaats waar iemand zich op dit spectrum positioneert verband houdt met zijn niveau van tolerantie. Deze veronderstelling is gebaseerd op de theorie waarin waarden centraal worden geplaatst (cf. Alford 2009:57, 163). Items op dit spectrum vragen of het leven van de respondent wordt geregeerd door waarden die afkomstig zijn van een bepaalde religie/ wereldbeschouwing, of door waarden van meer algemene aard, bijvoorbeeld ontleend aan de Verklaring van de rechten van de mens.

Verder zijn er items opgenomen waarmee nagegaan wordt in hoeverre respondenten als lid van een samenleving, groep of institutie in hun omgang met anderen bereid zijn om hun persoonlijke waarden ondergeschikt te maken aan een meer algemeen ideaal, zoals het bevorderen van multiculturaliteit, mensenrechten en vreedzaam samenleven. In navolging van Bennetts (1993) model van interculturele sensitiviteit zijn items opgenomen waarmee kan worden nagegaan op welke manier respondenten zich verhouden tot verschillen die er tussen mensen zijn: ontkenning, verdediging, minimalisering, acceptatie of integratie. De laatste positie betekent dat een respondent accepteert dat identiteit, inclusief wereldbeschouwing en religieuze identiteit, niet gebaseerd zijn op slechts één wereldbeschouwing of één religie. Er zijn ook items opgenomen om na te gaan in hoeverre respondenten bereid zijn om waarden, gewoonten en gedrag waar ze het zelf niet mee eens zijn te tolereren. Deze items zijn gebaseerd op vier categorieën van tolerantie die in de wetenschappelijke literatuur worden onderscheiden: exclusivisme, inclusivisme, pluralisme en dialogisch pluralisme (cf. Vermeer \& Van der Ven 2004).

Er wordt onderscheid gemaakt tussen een liberale en een geseculariseerde kijk op religieuze diversiteit. In de liberale visie worden diversiteit en het recht om te verschillen van een ander erkend en de dialoog met de ander wordt gestimuleerd. In de geseculariseerde visie wordt, volgens Mohler (2008:29-30), de mensheid gezien als bevrijd van de banden van de kerk en andere religieuze instituties. Religie wordt gezien als behorend tot de privésfeer en dus als iets dat buiten de publieke ruimte en buiten publieke instituties moet worden gehouden. In de vragenlijst is een item opgenomen waarmee kan worden vastgesteld waar respondenten zichzelf plaatsen in deze tweedeling.

Vreedzaam samenleven in een gemeenschap of een samenleving berust op een sociaal contract tussen de leden van zo'n gemeenschap. Het contract dient ruimte te scheppen voor diverse posities in de samenleving en ontspruit aan een gezamenlijk besluit van rationele individuen. Vandaar dat in de vragenlijst items zijn opgenomen die bedoeld zijn om te peilen in hoeverre respondenten bereid zijn om zo'n contract aan te gaan met de bedoeling om vreedzaam samen te leven met mensen die een andere godsdienst aanhangen dan zijzelf. Ware tolerantie heeft niet zijn oorsprong in opportunisme dat andere religies slechts tolereert uit eigenbelang of ten behoeve van een oppervlakkige vorm van samenleven. Ware tolerantie heeft een oprechte belangstelling voor de ander en zijn godsdienst, en is erop gericht om zoveel mogelijk van die ander en zijn godsdienst aan de weet te komen (Van der Walt 2007:213), onder andere gebaseerd op het christelijke gebod om de naaste lief te hebben.

Speciaal onder jongeren doen zich vandaag de dag tekenen voor van een oplevende spiritualiteit. Hoe meer iemand betrokken is op de dogma's van een religieuze institutie die de gewetens van zijn leden bindt, hoe minder tolerant zo iemand zal zijn ten opzichte van mensen die hun visie en overtuiging ontlenen aan een andere godsdienst. Het omgekeerde zal ook waar zijn: hoe meer iemand zich koestert in authentieke spiritualiteit, hoe waarschijnlijker het is dat zo iemand tolerant is ten opzichte van de visie van anderen (Mohler 2008). Daarom zijn er items opgenomen die moeten duidelijk maken of respondenten zichzelf meer zien als spiritueel, of zich meer verbonden weten met het grote verhaal van een historisch gegroeide religieuze groepering.

\section{Methode van onderzoek}

De bedoeling van de vragenlijst is om de mate van religieuze tolerantie te meten bij studenten die in het laatste jaar van hun lerarenopleiding zitten. 
Er werden 49 stellingen geformuleerd die nauw aansloten bij de theorie. Respondenten konden op deze stellingen reageren door op een vijfpunt Likertschaal aan te geven in hoeverre ze het met de betreffende stelling eens zijn. In dit soort onderzoek is deze schaal heel gebruikelijk (Smith \& Roodt 2003:63). Omdat het lastig is om de absolute gelijkheid van de intervallen tussen de vijf punten te bewijzen, zijn slechts de uitersten van de schaal benoemd ('sterk mee oneens' en 'sterk mee eens'). Voorafgaande aan deze stellingen werden vijf algemene vragen gesteld nadat de respondent verzekerd was van de vrijheid om de vragenlijst niet in de vullen en op de hoogte gebracht was van de vertrouwelijke behandeling van de antwoorden.

De tweede stap was het zicht krijgen op de psychometrische gegevens van de vragenlijst. Daartoe werd deze vertaald in vier talen en afgenomen bij vijf groepen studenten in het laatste jaar van hun opleiding tot leraar. Eén groep studenten was afkomstig uit Nederland, één uit India en drie groepen waren afkomstig uit Zuid-Afrika. Deze landen werden niet alleen geselecteerd omdat de onderzoekers goed op de hoogte zijn van het onderwerp en gemakkelijke toegang tot respondenten hebben, maar ook omdat zij verspreid zijn over de gehele wereld (Azië, Europa, het mondiale zuiden) en over het ontwikkelingsspectrum: in de classificatie van de Wereldbank is Nederland een hoog-inkomen-land, ZuidAfrika een hooggemiddeld-inkomen-land en India een laaggemiddeld-inkomen-land.

Nadere gegevens over deze respondentengroepen worden in het resultatenhoofdstuk weergegeven. Het onderzoeksproject is gestart door Driestar Christian University (Nederland) met één campus en North-West University (Zuid-Afrika) met drie campussen. De drie Zuid-Afrikaanse campussen waren nodig om voldoende diversiteit in taal en cultuur te waarborgen. Persoonlijke contacten leidden ertoe dat er ook een groep respondenten uit India (één campus) heeft meegedaan in deze fase.

Op de gegevens van deze eerste afname werden enkele statistiche analyses uitgevoerd, namelijk een exploratieve factoranalyse, enkele confirmatieve factoranalyses en betrouwbaarheidsonderzoeken (berekening van de Cronbach's alfa). Dit werd gedaan om de psychometrische karakteristieken van de vragenlijst vast te stellen. Ook werd een beschrijvende statistiek uitgevoerd om een eerste indruk te krijgen van de stand van religieuze tolerantie bij studenten die in het laatste jaar van hun lerarenopleiding zitten.

\section{Resultaten}

\section{Factoranalyses}

De eerste afnameronde leverde een totale dataset op met 423 bruikbare reacties. Daarop werd een exploratieve factoranalyse uitgevoerd (Osborne 2014). Factoranalyse word t uitgevoerd om een (grote) hoeveelheid geobserveerde variabelen te beschrijven in termen van een kleiner aantal niet-geobserveerde latente variabelen (factoren). Factoranalyse is dus bedoeld om de patronen en structuren die onder de data liggen zichtbaar te maken. Bovendien is factoranalyse gericht op reductie van het aantal variabelen (Field 2009). In dit onderzoek ging het er dus om dat de 49 stellingen gereduceerd zouden worden tot een kleiner aantal onderliggende variabelen (factoren). Vanuit de theorie bezien, zouden dat er dus acht moeten zijn. Omdat de factoranalyse aanvankelijk bedoeld was om te onderzoeken of er acht latente variabelen te onderscheiden waren, is er sprake van een exploratieve factoranalyse.

Een vrije rotatie leverde vijftien factoren op. Op deze factoren laadden 42 stellingen hoog genoeg $(>0,40)$. Deze factoren verklaarden samen 62,35 procent van de variantie. De betrouwbaarheid van het geheel van deze 42 stellingen werd vastgesteld door de alfacoëfficiënt te berekenen. Die bedroeg 0,85 . De hoogte van de alfacoëfficiënt was bevredigend, de hoeveelheid verklaarde variantie was enigszins bevredigend, maar het aantal factoren was dat niet. Het aantal factoren was te groot met als gevolg dat op sommige factoren slechts één of twee stellingen een lading hadden die hoog genoeg was. Als gevolg hiervan was een goede interpretatie van de factoren moeilijk.

Daarom werd vervolgens op de totale dataset een confirmatieve factoranalyse uitgevoerd met een gedwongen rotatie van acht factoren. De bedoeling was om na te gaan of de acht clusters van stellingen in de vragenlijst door deze analyse zouden worden bevestigd. De acht factoren in deze oplossing bleken goed te interpreteren. Er waren 37 stellingen die voldoende hoog $(>0,40)$ op deze acht factoren laadden. Met elkaar verklaarden ze 50,10 procent van de variantie. In Tabel 1 is te zien hoe de factoren gelabeld zijn en welke stellingen er voldoende hoog op de betreffende factor laadden.

\section{Acht variabelen (factoren)}

Hierboven werd gemeld dat de confirmatieve factoranalyse acht factoren opleverde die goed te interpreteren zijn. In Tabel 1 zijn ze te zien. Hier wordt beschreven wat de gevonden factoren betekenen.

De eerste factor is 'respect en vertrouwen'. Daarbij gaat het om vertrouwen in de eigen overtuigingen en het respect dat men van daaruit heeft voor de overtuigingen van anderen, ook als die afwijken van de eigen overtuigingen. Bij 'waarde van de eigen religie' moet worden gedacht aan de rol die religie speelt in de eigen overtuigingen en in de gedachten die men over anderen heeft. 'Universele set van waarden', de

TABEL 1: Gegevens van de acht factoren analyse op de gehele dataset.

\begin{tabular}{lcc}
\hline Factor & Stelling & Cronbach's alfa \\
\hline 1. Respect en vertrouwen & $30,31,36,40,46,47,48,50,52$ & 0.75 \\
2. Waarde van de eigen religie & $14,15,33,34,38,41$ & 0.77 \\
3. Universele set van waarden & $9,10,11,12,23$ & 0.66 \\
4. Oordeel over anderen & $6,22,24,25$ & 0.66 \\
5. Impact van de context & $5,43,44,49$ & 0.55 \\
6. Impact van de context & $28,29,42$ & 0.48 \\
7. Openheid voor verandering & $17,18,19$ & 0.54 \\
8. Ontmoeting met anderen & $4,7,8$ & 0.47 \\
\hline Totaal & & $\mathbf{0 . 7 8}$ \\
\hline
\end{tabular}


derde factor, duidt op een set van waarden die onafhankelijk van religie bestaat. Een respondent die hoog op deze factor scoort, vindt dat de waarden van een andere religie de omgang met een aanhanger van die religie niet in de weg mogen staan. De factor 'oordeel over anderen' drukt uit in hoeverre men onverschillig is ten opzichte van wat andere mensen denken en doen.

Er zijn twee factoren die hetzelfde label dragen 'impact van de context'. Bij beide factoren gaat het om de relatie tussen de respondent en de omgeving. In factor 5 ligt het accent meer op de diversiteit van die omgeving. In factor 6 gaat het meer om de betrokkenheid van de respondent op die omgeving. Factor 7 ('openheid voor verandering') gaat over de herkomst en de stabiliteit van de waarden van de respondent. De laatste factor is 'ontmoeting met anderen'. Die drukt uit hoe een respondent zich in het algemeen voelt ten opzichte van andere mensen.

\section{Betrouwbaarheid}

Berekening van de Cronbach's alfa over deze acht factoren leverde een waarde van 0,78 op. De interne consistentie van deze acht factoren als geheel is dus goed te noemen. Ook per factor werd de Cronbach's alfa berekend. In Tabel 1 zijn de gegevens van de acht factoren oplossing weergegeven. De alfacoëfficiënt van twee factoren bleek groter te zijn dan 0,70 (respect en vertrouwen, waarde van de eigen religie). De alfacoëfficiënten van vier andere factoren waren aanvaardbaar, maar twee waren niet aanvaardbaar (openheid voor verandering; openheid voor ontmoeting met anderen).

Deze acht factoren oplossing is ook toegepast op de vijf subgroepen (subsets) waaruit de totale respondentengroep was samengesteld. Naar verwachting laadden bij deze subgroepen niet dezelfde stellingen even hoog op dezelfde factoren. De betrouwbaarheid (alfacoëfficiënt) in de subgroepen was, op die van de Nederlandse subgroep na, bevredigend. Opvallend is dat de verklaarde variantie in de subgroepen steeds groter is dan die in de totale groep $(50.10 \%)$.

\section{Beschrijvende statistiek}

Ondanks het feit dat de vragenlijst moet worden herzien om betere psychometrische gegevens op te leveren, werd enige beschrijvende statistiek uitgevoerd. Dit geeft enigszins een beeld van de mate van religieuze tolerantie bij de 423 respondenten. Tabel 3 geeft een selectie van items uit de vragenlijst die rechtstreeks verband houden met de theorie die hierboven is weergegeven. In die tabel is weergegeven hoe het totaal van de respondentengroep heeft gereageerd op de vijfpuntschaal van de vragenlijst. Het samenvoegen van de antwoordcategorieën 'bijna helemaal mee eens' en 'helemaal mee eens' geeft een aanduiding van de mate van religieuze tolerantie in de groep studenten die in hun laatste studiejaar zitten. Hierbij moet worden bedacht dat de vragenlijst wordt herzien naar aanleiding van deze eerste afname (zie de volgende paragraaf).

De antwoorden op de items 7, 10, 11 en 48 tonen aan dat de groep studenten tolerant is tegenover andere mensen, ongeacht de godsdienstige verschillen. Deze studenten lijken het belang van een vreedzaam samenleven in een gemeenschap te onderkennen. De meeste antwoorden op de andere items zijn in overeenstemming met deze algemene houding van religieuze tolerantie. Maar er zijn ook antwoorden die lijken te duiden op een houding van negativiteit, onverschilligheid, wantrouwen en een gebrek aan empathie ten opzichte van mensen die een andere godsdienst aanhangen $(6,14,22,24,25,28,29,32,44,45,49)$.

\section{Ethische overwegingen}

Aan de respondenten is te kennen gegeven dat de gegevens volledig anoniem zullen worden verwerkt. Zij hebben volledig vrijwillig aan het onderzoek meegewerkt, zonder door iemand onder druk gezet te zijn. Zij waren zich ervan bewust dat ze op ieder moment het invullen van de vragenlijst konden stoppen, zonder nadelige gevolgen voor henzelf. De respondenten was geen beloning voor het invullen van de vragenlijst in het vooruitzicht gesteld. Een ethiekverklaring voor dit project is verkregen van de Noord-West Universiteit onder wiens toezicht dit project wordt uitgevoerd.

De auteurs verklaren hierbij dat zij geen financiële of persoonlijke relatie hebben met enige partij die hen ten nadele of ten voordele kon beïnvloeden bij het schrijven van dit artikel.

\section{Discussie}

Op grond van de theorie die ten grondslag ligt aan de vragenlijst werd verondersteld dat er acht clusters van vragen zouden zijn die de mate van religieuze tolerantie zichtbaar maken: ontmoeting met anderen; universele set van waarden; openheid voor verandering; impact van de context; beoordeling van anderen; respect/eerbied; opvattingen over vrijheid; begrip en empathie. Tabel 1 laat zien dat de empirische gegevens zich niet precies laten voegen in deze acht clusters. Zes ervan werden wel teruggevonden in de factorstructuur: ontmoeting met anderen; universele set van waarden; openheid voor

TABEL 2: Gegevens van de vijf subsets.

\begin{tabular}{|c|c|c|c|c|c|}
\hline Land & Taal & $N$ & Aantal stellingen & Verklaarde variantie (\%) & Cronbach's alfa \\
\hline Nederland & Nederlands & 68 & 42 & 58.32 & 0.44 \\
\hline \multirow[t]{3}{*}{ Zuid-Afrika } & Afrikaans & 102 & 40 & 56.62 & 0.71 \\
\hline & Engels & 75 & 45 & 60.28 & 0.89 \\
\hline & Tswana & 78 & 45 & 57.07 & 0.86 \\
\hline India & Engels & 100 & 42 & 53.92 & 0.75 \\
\hline Totaal & & 423 & 37 & 50.10 & 0.78 \\
\hline
\end{tabular}


TABEL 3: Selectie van items die direct verband hebben met religieuze tolerantie

\begin{tabular}{|c|c|c|c|c|c|c|c|}
\hline Item & & $\begin{array}{c}\text { Helemaal } \\
\text { oneens }\end{array}$ & . & . & . & $\begin{array}{l}\text { Helemaal } \\
\text { eens }\end{array}$ & $\begin{array}{l}\text { Totaal van twee } \\
\text { laaste kolommen }\end{array}$ \\
\hline \multirow[t]{2}{*}{ 6. Het kan me niet schelen wat andere mensen denken en vinden. } & $N$ & 93 & 84 & 123 & 65 & 57 & \\
\hline & $\%$ & 22 & 20 & 29 & 15 & 14 & 29 \\
\hline \multirow[t]{2}{*}{ 7. Ik wil graag vriendschappelijk omgaan met andere mensen. } & $N$ & 14 & 8 & 22 & 124 & 255 & \\
\hline & $\%$ & 3 & 2 & 5 & 29 & 60 & 89 \\
\hline \multirow{2}{*}{$\begin{array}{l}\text { 10. Alle mensen moeten goed met elkaar kunnen omgaan, ongeacht } \\
\text { welke waarden en normen ze belangrijk vinden. }\end{array}$} & $N$ & 20 & 17 & 49 & 109 & 228 & \\
\hline & $\%$ & 5 & 4 & 12 & 26 & 54 & 81 \\
\hline \multirow{2}{*}{$\begin{array}{l}\text { 11. Er zijn waarden en normen die voor alle mensen belangrijk } \\
\text { zouden moeten zijn, ongeacht hun religie/levensbeschouwing. }\end{array}$} & $N$ & 15 & 9 & 42 & 108 & 249 & \\
\hline & $\%$ & 4 & 2 & 10 & 26 & 59 & 85 \\
\hline \multirow{2}{*}{$\begin{array}{l}\text { 14. Waarden en normen die voortvloeien uit een andere religie/ } \\
\text { levensbeschouwing kunnen geen richtlijn vormen voor mijn leven. }\end{array}$} & $N$ & 76 & 81 & 129 & 79 & 58 & \\
\hline & $\%$ & 18 & 19 & 30 & 19 & 14 & 29 \\
\hline \multirow[t]{2}{*}{ 22. Het kan mij niet schelen wat andere mensen denken en doen. } & $N$ & 90 & 113 & 102 & 64 & 54 & \\
\hline & $\%$ & 21 & 27 & 24 & 15 & 13 & 28 \\
\hline \multirow{2}{*}{$\begin{array}{l}\text { 24. Het maakt me niet uit wat mensen denken en doen in verband } \\
\text { met hun religie/levensbeschouwing. }\end{array}$} & $N$ & 54 & 83 & 121 & 102 & 63 & \\
\hline & $\%$ & 13 & 20 & 29 & 24 & 15 & 39 \\
\hline $\begin{array}{l}\text { 25. De ideeën en acties van andere mensen in verband met hun } \\
\text { religie/levensbeschouwing storen mij in het geheel niet. }\end{array}$ & $\%$ & 10 & 24 & 31 & 23 & 13 & 36 \\
\hline \multirow{2}{*}{$\begin{array}{l}\text { 28. Ik kan mijzelf verplaatsen in een ander die een totaal andere } \\
\text { religie/levensbeschouwing heeft dan ikzelf. }\end{array}$} & $N$ & 94 & 60 & 112 & 96 & 61 & \\
\hline & $\%$ & 22 & 14 & 26 & 23 & 14 & 27 \\
\hline \multirow{2}{*}{$\begin{array}{l}\text { 29. Ik heb een sterke neiging om mensen met een andere religie/ } \\
\text { levensbeschouwing te vertrouwen. }\end{array}$} & $N$ & 61 & 102 & 141 & 72 & 46 & \\
\hline & $\%$ & 14 & 24 & 33 & 17 & 11 & 28 \\
\hline \multirow{2}{*}{$\begin{array}{l}\text { 32. Ik geloof in een maatschappij met één set aan waarden die door } \\
\text { iedereen gedeeld wordt. }\end{array}$} & $N$ & 82 & 71 & 108 & 94 & 68 & \\
\hline & $\%$ & 19 & 17 & 26 & 22 & 16 & 38 \\
\hline \multirow{2}{*}{$\begin{array}{l}\text { 44. Ik zou wel willen verhuizen naar een maatschappij waarin alle } \\
\text { mensen het leven op eenzelfde manier benaderen als ik dat doe. }\end{array}$} & $N$ & 72 & 86 & 99 & 84 & 82 & \\
\hline & $\%$ & 17 & 20 & 23 & 20 & 19 & 39 \\
\hline \multirow{2}{*}{$\begin{array}{l}\text { 45. Ik ga ervan uit dat de verschillen tussen mensen zó groot zijn, } \\
\text { dat een werkelijk vreedzame samenleving onmogelijk is. }\end{array}$} & $N$ & 68 & 96 & 109 & 96 & 54 & \\
\hline & $\%$ & 16 & 23 & 26 & 23 & 13 & 36 \\
\hline \multirow{2}{*}{$\begin{array}{l}\text { 48. Ik vind dat mensen de verschillen die er in de samenleving zijn, } \\
\text { moeten respecteren. }\end{array}$} & $N$ & 7 & 10 & 47 & 149 & 210 & \\
\hline & $\%$ & 2 & 2 & 11 & 35 & 50 & 85 \\
\hline $\begin{array}{l}\text { 49. Ik vind het moeilijk om me in te leven in de gedachtegang van } \\
\text { mensen die er heel andere opvattingen op na houden dan ikzelf. }\end{array}$ & $N$ & 47 & 70 & 120 & 103 & 82 & \\
\hline
\end{tabular}

verandering; impact van de context; beoordeling van anderen; respect/eerbied. De laatste twee clusters zijn in de data niet terug te vinden. Er werden wel twee nieuwe factoren gevonden: waarde van de eigen religie en afzondering van de samenleving.

Na de eerste afname waarover hier wordt gerapporteerd is het duidelijk dat er nog geen bevredigende factorstructuur is gevonden. Teveel stellingen laadden hoog op factoren waar ze theoretisch gezien niet toe gerekend moeten worden. De oorzaak hiervan kan worden gezocht in de formulering van de stellingen. Sommige stellingen liggen wat formulering betreft te dicht bij elkaar zodat het verschil in betekenis nagenoeg niet te onderscheiden is. Sommige stellingen waren vermoedelijk te moeilijk geformuleerd om goed begrepen te worden. Soms werden bepaalde onderdelen van stellingen die identiek bedoeld waren niet op dezelfde wijze geformuleerd. Ook de alfacoëfficiënt van sommige subschalen was nog niet bevredigend. Deze problemen kunnen worden aangepakt door herformulering van de stellingen.

Mogelijk schuilt er achter de instabiliteit van de gevonden factorstructuur ook een inhoudelijke oorzaak. Tussen de respondenten in de vijf subsets bestaan culturele verschillen. Die houden verband met de verschillende maatschappelijke contexten waarin de respondenten leven. Het is waarschijnlijk dat deze verschillen invloed hebben op het antwoordgedrag en daarmee op de factorstructuren die in de verschillende subsets werden gevonden. Het is de vraag hoe die culturele verschillen kunnen worden meegenomen in de geplande herziening van de vragenlijst. Het theoretisch raamwerk zal herziening moeten ondergaan, in die zin dat het de verschillen in patronen tussen culturen voldoende weerspiegelt.

\section{Conclusie}

Ondanks de geconstateerde tekortkomingen in de vragenlijst, die een tweede valideringsronde nodig maken, konden wel enkele conclusies worden getrokken met betrekking tot de mate van religieuze tolerantie van studenten in het laatste jaar van de lerarenopleiding. Hoewel de respondenten in het algemeen een tolerante houding hebben ten opzichte van mensen met wie ze op godsdienstig vlak verschillen, vertonen ze toch ook een zekere mate van gerichtheid naar binnen, onverstoorbaarheid, onverschilligheid, wantrouwen en een gebrek aan empathie. Deze laatste gerichtheid zou voor lerarenopleidingen reden kunnen zijn tot aanpassingen in het curriculum.

Religieuze tolerantie vormt één van de sleutels tot het vreedzaam samenleven in een samenleving die in toenemende mate godsdienstig en cultureel divers wordt. Het onderzoek waarover hierboven wordt gerapporteerd is dus van veel belang, aangezien dit moet leiden tot een instrument waarmee de religieuze tolerantie van studenten in het laatste jaar van de lerarenopleiding vastgesteld moet 
kunnen worden. De eerste afname van het instrument heeft bepaalde tekortkomingen aan het licht gebracht, en belooft ook kansen voor verbetering ervan. Het streven blijft om een instrument te verkrijgen waarmee de religieuze tolerantie van leraren in opleiding en leraren in de praktijk te kunnen vaststellen. Het is de vraag of het mogelijk zal zijn om met één vragenlijst te kunnen werken in verschillende landen/ culturen, of dat er verschillende varianten van de vragenlijst moeten worden gehanteerd. Voortgaand empirisch onderzoek en het bijstellen van het theoretisch kader zullen nodig zijn om op die vraag antwoord te verkrijgen.

Als er een betrouwbaar en valide meetinstrument is ontwikkeld kan het onderzoeksproject zich in twee richtingen verder ontwikkelen. Enerzijds kan het gebruikt worden om de vraag te beantwoorden welke verschillen er zijn tussen de mate van religieuze tolerantie van leraren in opleiding die zich in verschillende landen bevinden.

Gesteld kan worden dat religieuze tolerantie van studenten in een bepaald land in hoge mate bepaald wordt door een reeks contextuele factoren. Daartoe kunnen gerekend worden: bevolkingssamenstelling, de geschiedenis van het land, het onderwijs dat studenten genoten hebben, de opvoeding die studenten thuis ontvingen, de effecten van (sociale) media, de invloed van leeftijdsgenoten, het waardenstelsel van de samenleving en de cultuur, en de politieke omgeving. In een vergelijking tussen landen moet de invloed van die contextuele factoren op religieuze tolerantie worden belicht (cf. Wolhuter 2008:326). In het ontwerpen van een programma om tolerantie te bevorderen (zie volgende alinea) zal terdege kennis moeten worden genomen van deze contextuele antecedenten. Daarom zullen in vervolgonderzoek de uitkomsten van de beschrijvende statistiek (gemiddelden en frequentieverdelingen) en de factoranalyses voor elk van de landen moeten worden geïnterpreteerd met inachtneming van de nationale context van die landen.

Een tweede mogelijke richting is dat de afname van het meetinstrument wordt gebruikt bij het beantwoorden van de vraag hoe de religieuze tolerantie van leraren in opleiding kan worden bevorderd. Het onderzoeksproject waarvan dit het eerste stadium is, heeft dus zowel theoretische als practische waarde.

\section{Erkenning \\ Tegenstrijdige belangen}

De auteurs verklaren dat zij geen financiële of persoonlijke verbintenissen hebben die hen op een ongepaste wijze hebben beïnvloed bij het schrijven van dit artikel.

\section{Bijdragen auteurs}

N.A.B. is verantwoordelijk voor enkele kleinere onderdelen van de theoretische achtergrond en voor de statistische analyses. Hij vertaalde de tekst in het Nederlands, zette hem in het juiste formaat en redigeerde de eindversie.
A.d.M., J.L.v.d.W. en F.J.P. verzorgden het grootste deel van het theoretische raamwerk. N.A.B., C.C.W. and J.L.v.d.W. zijn gezamenlijk verantwoordelijk voor de resultatenparagraaf, de discussie en de conclusies.

\section{Literatuurverwijzingen}

Alford, H., 2009, How to live: A search for wisdom from old people, Twelve Books, New York.

Bennett, M.J., 1993, 'Towards ethnorelativism: A developmental model of intercultural sensitivity', in R.M. Paige (ed.), Education for the intercultural experience, pp. 21-71, Intercultural Press, Yarmouth, ME.

Bering, J., 2010, The God instinct: The psychology of souls, destiny and the meaning of life (Kindle Locations 147-190), NB Ltd., Kindle Edition.

Biesta, G., 2013, The beautiful risk of education, Paradigm Publishers, Boulder, CO.

Boer, F., 2014, 'De rijkgeschakeerde omgeving van de adolescent', Tijdschrift voor Psychotherapie 40(1), 6-19. http://dx.doi.org/10.1007/s12485-014-0002-7

Boersma, P., 2012, Personal communication, Besturenraad, Voorburg, The Netherlands.

Bol, S., 2015, 'Islamitische gebedsgroep vraagt uiterste van tolerantie', viewed 30 May 2015, from https://www.nd.nl/nieuws/binnenland/islamitische-gebedsoproepvraagt-uiterste-van.779313.lynkx

Bower, C., 2005, Open minds, closed minds and Christianity, Aardvark Press, Valyland, Cape Town.

Bucher, K.T. \& Manning, M.L., 2010, 'Challenges and suggestions for safe schools', The Clearing House: A Journal of Educational Strategies, Issues and Ideas 76(3), 160-164. http://dx.doi.org/10.1080/00098650309601995

Coleman, E.B. \& White, K., 2011, Religious tolerance, education and the curriculum, Sense Publishers, Rotterdam.

Collins, J.R., 2009, 'Redeeming the enlightenment: New histories of religious toleration', The Journal of Modern History 81(3), 607-636. http://dx.doi.org/ 10.1086/599275

Cush, D. \& Francis, D., 2006, "“Positive pluralism” to awareness, mystery and value: A case study in religious education curriculum development', British Journal of Religious Education 24(1), 52-67. http://dx.doi.org/10.1086/599275

Field, A., 2009, Discovering statistics using SPSS, 3rd edn., Sage, Los Angeles, CA.

Furedi, F., 2012, 'On tolerance', Policy 28(2), 30-37.

Galeotti, A.E., 2014, 'The range of toleration: From toleration as recognition back to disrespectful tolerance', Philosophy and Social Criticism 41(2), 93-110. viewed 23 November 2014, from http://psc.sagepub.com/content/early/2014/11/20/ 0191453714559424

Goodin, R.E., 2006, What's wrong with terrorism?, Polity Press, Cambridge.

Gray, J., 2009, Gray's anatomy, Allen Lane, London.

Grayling, A.C., 2002, The meaning of things, Phoenix, London.

Grayling, A.C., 2010, Thinking of answers, Bloomsbury, London.

Hart, D., Atkins, R. \& Ford, D., 1998, 'Urban America as a context for the development of moral identity in adolescence', Journal of Social Issues 54, 513-530. http:// dx.doi.org/10.1111/j.1540-4560.1998.tb01233.x

Ignatieff, M., 2004, The lesser evil: Political ethics in an age of terror, Edinburgh University Press, Edinburgh. http://dx.doi.org/10.3366/edinburgh/97807486187 29.001.0001

Jansen, J.D., 2010, Knowledge in the blood: Confronting race and the Apartheid past, Stanford University Press, Stanford, CA.

Jarvis, J., 2009, 'Teacher identity in a context of religious diversity', Alternation Special Edition 3(1), 157-176.

Joe, D., 2011, Review of F. Furedi's On Tolerance: A defence of moral independence, Continuum Publishing, New York, viewed 2 July 2014, from www.manchestersalon. org.uk/on-tolerance-frank-furedi.pdf

Mohler, A., 2008, Atheism remix, Crossway Books, Wheaton, IL.

Morton, A., 1998, Philosophy in practice, Blackwell Publishers, Malden, MA.

Nussbaum, M.C., 2001, Upheavals of thought: The intelligence of emotions, Cambridge University Press, Cambridge.

Nussbaum, M.C., 2012, The new religious intolerance, Belknap Press, Cambridge, MA.

Olthuis, J.H., 2012, 'A vision of and for love: Towards a Christian post-postmodern worldview', Koers, Bulletin for Christian Scholarship 77(1), Art. No 28, 7 p. http:// dx.doi.org/10.4102/koers.v77i.28

Osborne, J.W., 2014, Best practices in exploratory factor analysis, CreateSpace Independent Publishing Platform, Charleston, SC.

Pape, R., 2005, Dying to win: The strategic logic of suicide terrorism, Random House, New York.

Potgieter, F.J., 2015, 'Beyond tolerance: Educating for religious respect and hospitality in pedagogic-multilogical sanctuaries', in N. Popov (ed.), Quality, social justice and accountability in education worldwide. BCES Conference Books, 13(1), pp. 53-59, accountability in education wor
Investpress, Sofia, Bulgaria.

Potgieter, F.J. \& Van der Walt, J.L., 2014, 'Is religious fundamentalism our default spirituality?: Implications for teacher education', HTS Teologiese Studies/Theological Studies 70(1), Art. No 2082, 9 p. http://dx.doi.org/10.4102/hts.v70i1.2082

Potgieter, F.J., Van der Walt, J.L. \& Wolhuter, C.C., 2014, 'Towards understanding (religious)' (in)tolerance in education', HTS Teologiese Studies/Theological Studies 70(3), Art. No 1977, 8 p. http://dx.doi.org/10.4102/hts.v70i3.1977 
Qualifications and Curriculum Authority (United Kingdom), 2004, Religious education The non-statutory national framework, viewed 20 July 2013, from http://www. theredirectory.org.UK/public_docs/Non-statutory_national_Framework_/ RE 0410.pdf

Qualifications and Curriculum Authority (United Kingdom), 2010, Religious Education in English schools: Non-statutory guidance DCSF (2010), viewed 20 July 2013 from $h t t p: / / w w w . t e a c h e r n e t . g o v . u k / p u b l i c a t i o n s$

Richardson, J.W., Imig, S. \& Flora, K., 2014, 'Evaluating school leadership through an international experience', International Journal of Leadership in Education 17(3), 353-369. http://dx.doi.org/10.1080/13603124.2013.817611

Roux, C.D., 2000, 'Multireligious education: An option for South Africa in the New Education System', British Journal of Religious Education 22(3), 173-180. http:// dx.doi.org/10.1080/0141620000220305

Roux, C.D., 2006, 'Children's spirituality in social context: A South African example', International Journal of Children's Spirituality 11(1), 151-163. http://dx.doi.org/ $10.1080 / 13644360500504462$

Sardoc, M., 2010, 'Toleration, respect and recognition: Some tensions', Educationa Philosophy and Theory 42(1), 6-8. http://dx.doi.org/10.1111/j.1469-5812.2009. 00546.x

Saulius, T., 2013, "What is "tolerance" and "tolerance education"? Philosophical perspectives', Ugdymas, Kuno Kultura, Sportas = Education, Physical Training, Sport 89(2), 49-56.

Schreiner, P., 2005, Religious education in Europe, Comenius Institute, Oslo University, viewed 9 November 2012, from http://resources.eun.org/etwinning/europa2.pdf

Schulz, W., Ainley, J., Fraillon, J., Kerr, D. \& Losito, B., 2010, Initial findings from the IEA International Civic and Citizenship Education Study, International Association for the Evaluation of Educational Achievement (IEA), Amsterdam.

Skiba, R. \& Peterson, R., 1999, 'The dark side of zero tolerance: Can punishment lead to safe schools?', Phi Delta Kappa International, viewed 23 March 2016, from http://www.pdkintl.org/kappan/kski9901.htm

Slot, W. \& van Aken, M., 2013, Psychologie van de adolescentie, ThiemeMeulenhoff, Amersfoort.

Smith, S. \& Roodt, G., 2003, 'An evaluation of response scale formats of the culture assessment instruments', SA Journal of Human Resource Management 2, 60-75. http://dx.doi.org/10.4102/sajhrm.v1i2.10
The curriculum review group, 2004, A curriculum for excellence, Scottish executive, Edinburgh.

Tobing, E., 2013, 'Promoting religious tolerance: What does religious tolerance mean?', The Prospect, viewed 14 January 2013, from http://www. theindonesianinstitute.org/pers020706.htm

Van der Walt, B.J., 2007, Transforming power: Challenging contemporary secular society, Institute for Contemporary Christianity in Africa, Potchefstroom.

Van der Walt, J.L., 2014, Measuring religious tolerance in education: Towards an instrument for measuring religious tolerance among educators and their students worldwide, viewed 10 June 2015, from https://www.driestar-educatief.nl/ medialibrary/Driestar/Engelse-website/Documenten/2014-VanderWaltMeasuring-religious-tolerance-in-education.pdf

Van der Walt, J.L., Potgieter, F.J. \& Wolhuter, C.C., 2010, 'The road to religious tolerance in education in South Africa (and elsewhere): A possible "Martian Perspective"', Religion, State and Society 38(1), 29-52. http://dx.doi.org/10.1080/ 09637490903500507

Van Schoonacker-de Groot, A., 2011, 'The effect of study abroad on the development of student teachers: A literature study', Journal of European Teacher Education Network 6, 44-57.

Vermeer, P. \& Van der Ven, J.A., 2004, 'Looking at the relationship between religions: An empirical study among secondary school students' Journal of Empirical Theology 17(1), 36-59. http://dx.doi.org/10.1163/1570925041208899

Visanmiu, T., 2012, 'What is the meaning of tolerance in the modern world?', Theodorvisanmiu, viewed 26 April 2012, from http://theodorvisanmiu.wordpress. com/2012/04/26/what-is-the-meaning-of-tolerance-in-the-modern-world

Visser-Vogel, E., 2015, 'Religious identity development of orthoprax Muslim adolescents in the Netherlands', PhD thesis, Utrecht University.

Wolhuter, C.C., 2008, 'Review of the Review: Constructing the identity of comparative education', Research in Comparative and International Education 3(4), 323-344. http://dx.doi.org/10.2304/rcie.2008.3.4.323

Wolhuter, C.C., 2016, 'How should comparative international education practitioners secure comparative international education's place in teacher education?', in P. Kubow \& A. Blosser (eds.), Teaching comparative education: Trends and issues informing practice, Symposium, Oxford.

Wright, R., 2009, The evolution of god, Little, Brown \& Company, New York. 